\title{
Transboundary Water Conflicts as Postcolonial Legacy (the Case of Nile Basin)
}

\author{
A.M. Abdullah \\ Al-Zaeem Al-Azhari University, Khartoum, Sudan \\ C. Dyduck, T.Y. Ahmed \\ RUDN University, Moscow, Russian Federation
}

\begin{abstract}
It is not shortage or lack of water that leads to conflict but the way how water is governed and managed. It is said that water will be, much more than oil, the major geopolitical issue of the 21 st century. Although it is difficult to demonstrate this, it is clear that the increasing scarcity of the resource, on the one hand, and the configuration of its availability, on the other, are conflict-generating. In the particular case of the African continent, the large catchment basins of the Nile, Niger and Chad, shared by many states of unequal power, are the scene of inefficient hydro-diplomacy. Indeed, north to south, the Nile Delta is $161 \mathrm{~km}$ long and covers the coastline of Egypt from Alexandria in the west to Port Said in the east. Egypt with $100 \mathrm{mln}$ population is de facto the principal hydro-hegemon state in the Nile basin. Nevertheless, a couple of riparian states, as Ethiopia (105 mln population), have taken measures in order to challenge this status quo: the signature and launching of the Nile Basin Initiative (NBI), the signature of Cooperative Framework Agreement (CFA), the construction of the Grand Ethiopian Renaissance Dam (GERD) and the signing of the Declaration of Principles Agreement. The article attempts to analyse the urgency of the problem of water resources allocation in Africa with particular focus to the Nile basin and the complexity of agreements regulating the issue dating back to the colonial era. The study also emphasizes the difficulties bilateral and multilateral aids faced while trying to solve a conflict. As Nile for many states is not just a source of water, it is the host of a fragile ecosystem, essential for maintaining the environmental and ecological balance of North-East Africa.

Key words: Africa, water, conflict, Nile basin, Egypt, Sudan, Ethiopia, Nile Basin Initiative (NBI), Grand Ethiopian Renaissance Dam (GERD)
\end{abstract}

For citation: Abdullah, A.M., Dyduck, C. \& Ahmed, T.Y. (2020). Transboundary Water Conflicts as Postcolonial Legacy (the Case of Nile Basin). Vestnik RUDN. International Relations, 20 (1), 184-196. DOI: 10.22363/23130660-2020-20-1-184-196

Научная статья

\section{Трансграничные водные конфликты как постколониальное наследие (на примере бассейна Нила)}

\author{
А.М. Абдулла \\ Университет Аль-Заим Аль-Азхари, Хартум, Судан \\ С. Дидук, Т.Я. Ахмед \\ Российский университет дружбы народов, Москва, Российская Федерация
}

Причиной водных конфликтов является не нехватка воды, а то, как она распределяется. В будущем роль воды будет важнее, чем нефти, а водная проблема станет главной геополитической проблемой XXI в. Очевидно,

(C) Abdullah A.M., Dyduck C., Ahmed T.Y., 2020

This work is licensed under a Creative Commons Attribution 4.0 International License.

https://creativecommons.org/licenses/by/4.0/ 
что растущая нехватка водных ресурсов, с одной стороны, и неэффективные режимы их распределения и управления - с другой порождают конфликты. На Африканском континенте крупные водосборные бассейны Нила, Нигера и Чада разделены между целым рядом государств с различной мощностью и являются ареной водной дипломатии. Так, дельта Нила протянулась с севера на юг на 161 км и охватывает территорию от Александрии на западе до Порт-Саида на востоке. Египет со 100-миллионным населением де-факто является основным гидрогегемоном в бассейне Нила. Тем не менее, несколько прибрежных государств, таких как Эфиопия (105 млн населения), приняли меры, чтобы бросить вызов этому статус-кво, в том числе подписание и запуск Инициативы по бассейну Нила (NBI), подписание Рамочного соглашения о сотрудничестве (CFA), строительство «Великой плотины возрождения Эфиопии» и подписание Соглашения о декларации принципов. В статье предпринята попытка проанализировать актуальность проблемы распределения водных ресурсов в Африке с особым акцентом на бассейн Нила и сложность соглашений, регулирующих эту проблему еще с колониальных времен. В исследовании также подчеркиваются трудности, с которыми сталкивается разрешение данного конфликта на двусторонней и многосторонней основе. Для многих государств региона Нил является не просто источником воды, но и представляет собой хрупкую экосистему, необходимую для поддержания экологического баланса в Северо-Восточной Африке.

Ключевые слова: Африка, вода, конфликт, бассейн Нила, Египет, Судан, Эфиопия, Инициатива бассейна Нила (NBI), «Великая плотина возрождения Эфиопии»

Для цитирования: Abdullah A.M., Dyduck C., Ahmed T.Y. Transboundary Water Conflicts as Postcolonial Legacy (the Case of Nile Basin) // Вестник Российского университета дружбы народов. Серия: Международные отношения. 2020. Т. 20. № 1. C. 184-196. DOI: 10.22363/2313-0660-2020-20-1-184-196

\section{Introduction}

Water is the primary natural resource without which human life is impossible. Obviously, the growing scarcity of water resources represents a serious threat to humanity not just for certain regions, but also on a global scale. Speaking at the April 2000 UN General Assembly meeting with the "Millennium Report", UN Secretary General Kofi Annan called water supply to the world's population one of the most important tasks of the world community ${ }^{1}$. Environmental problems of hydrosphere are rapidly growing all over the world.

In current conditions a quarter of the world population has water deficit, more than one billion people have no access to clean water, and it is predicted that by 2025 the same number of people will live in conditions of "absolute water hunger". According to the World Water Council (WWC), by 2050 about $2 / 3$ of the world population will face a problem of shortage of freshwater resources ${ }^{2}$. The growing scarcity of

1 Annan K.A. "We the peoples: role of the United Nations in the twenty-first century". Report of the Secretary-General // United Nations Millennium Assembly. 2000. URL: https://www.un.org/en/events/ pastevents/pdfs/We_The_Peoples.pdf (accessed: 03.01.2020).

2 The United Nations world water development report 2019: leaving no one behind // United Nations. 2019. URL: water resources is a threat to humanity not only in certain regions, but on a global scale. Internationally, water is a major geopolitical issue. The mere distribution of freshwater resources on the planet can be described as extremely inequitable - only nine countries hold $60 \%$ of the resources, and of these, only Brazil, Canada, Indonesia, the Democratic Republic of Congo, Colombia and Russia have a surplus of freshwater resources in relation to the needs of their populations.

The exacerbation of water scarcity due to global population growth, improved living standards and increased economic output have led to strong competitive pressures for water use in recent decades. As a result, there are growing problems in the allocation of transboundary water resources, the use of which shared by several countries is often disputed. Indeed, the same watercourse often gives rise to divergent interests between the different riparian countries, interests which depend on the uses they have of the river. If navigation or nautical recreations, for example, do not alter the management of the watercourse, other uses may lead to qualitative or quantitative transformations. For example, the construction of dams or hydropower plants

https://unesdoc.unesco.org/ark:/48223/pf0000367306 (accessed: 03.01.2020). 
affects the regularity of the river (a priori virtuous modifications for the whole basin in terms of flood protection); pumping the river to irrigate agricultural land, produce electricity or for any other industrial use reduces its flow and generates pollution. In the latter cases, the use of the river by one country irrevocably modifies its course over its entire length and conditions the use of the river by the other riparian countries downstream [Amer, Adeel, Böer, Saleh 2017].

Due to its nature and the multiple uses that can be made of it, the river is destined to become a potential object of litigation if it crosses several countries [Bencala, Dabelko 2008]. If a river is shared, the different riparian countries are necessarily in unequal positions, each country being largely dependent on the use of the river by the upstream countries. This therefore necessarily favours the countries located on the upper river, and places the countries located closer to its mouth at a disadvantage [Mason 2004].

Several statesmen or representatives of international organizations, such as John Fitzgerald Kennedy in the early 1960s or Boutros Boutros-Ghali in 1991, had stressed the highly conflictual dimension that the water issue would take on, announcing that the 21 st century would be the century of water wars. To date, while no armed conflict has had the sharing of water as its main cause, there are many river basins where the transboundary sharing of water resources is either one of the reasons for the outbreak of armed conflict or a cause of tension that could lead to armed conflict [Tadesse 2008]. This is the case in the basins of the Mekong, Euphrates and Tigris rivers and the Jordan River. In this article, we will look more specifically at the case of the Nile basin and discuss the conflict between Egypt, Sudan and Ethiopia. This study will also try to highlight possible bilateral and multilateral cooperation implemented in order to find a point of convergence.

\section{The Nile and the Transboundary Agenda}

By its size, physiography, political and historical divisions, the ethnic, religious and linguistic diversity of its populations, and its sumptuous biodiversity, the Nile basin is very complex. It covers nearly three million $\mathrm{kms}$ $(10 \%$ of the surface area of the African continent) and $300 \mathrm{mln}$ people live there. This population will double by 2030 [Larbi 2010: 191-196]. This will inevitably have repercussions on agriculture and economic activities in the region, and thus on the uses of the river's waters. Moreover, except for Egypt and Kenya, all the riparian countries are among the 50 poorest nations in the world. According to experts, the potential of the river for the development of these African territories remains largely untapped.

The Nile basin countries are interdependent, and their development is undoubtedly linked to the hydrological cycle of the river. Coordinated management of the Nile's waters has created synergy among the different countries and sectors and is indeed helping to advance cooperation. If we take for example the case of Sudan, the country has three of the four major tributaries of the Nile (White Nile, Blue Nile, Sobat and Atbara). The average annual flow of the Nile is 84 billion cubic meters. More than $20 \%$ (of the country's territory) belong to the areas of internal runoff, including $5 \%$ to the Lake Chad basin [Abi Chacra 2005: 489-492]. The watercourses of the extreme eastern zone flow into the Red Sea. On the border with Ethiopia and Eritrea, seasonal watercourses the Gash and Baraka - play an important role. Their average annual flow is 0.6 and 0.5 billion cubic metres, respectively. The water availability of the Nile is highly uneven and largely dependent on rainfall. During dry periods, runoff is catastrophically reduced, reaching $15 \%$ of its average annual level in some years [Amer, Adeel, Böer, Saleh 2017]. Cutting down of forests along the Nile bed and its tributaries and forest-protected coastal plantations, excessive use of pastures, improper farming practices, etc. also have an impact on the decline. This leads to erosion of the coastline, washout of soil from coastal areas, especially in case of flooding, which leads to catastrophic consequences. Extremely severe floods occurred in the $1960 \mathrm{~s}$, 1978-1979, 1988, 1994, 1989-1999, 2006. During the last severe flood in 2013, 50,000 
people were killed and about 300,000 affected [Smirnova, Gukasyan 2019: 235].

During the first half of the 20th century, the patterns in the utilisation and management of the water of the Nile River were dictated by the interests of the United Kingdom ${ }^{3}$. The UK had a deep-rooted interest in controlling the water of the Nile, which was to provide irrigation for cotton plantations in the area which could provide raw material for its industries in Europe. This laid the foundation for water utilisation patterns that favoured Egypt at the expense of the interest of other riparian states [Markakis 1998: 51].

The main purpose of the British-Italian Protocol of April 15, 1891 was to establish the boundaries of the Nile Basin colonies. In addition, Italy pledged not to carry out work on the Nile tributary (Atbara River) that could significantly alter its flow [Vasiliev, Elkina 2018]. On May 15, 1902 Great Britain, representing the interests of Egypt and Sudan, concluded an agreement in Addis Ababa, under which the Emperor of Ethiopia Menelik II pledged not to build any hydraulic structures on the Blue Nile and Lake Tanah or River Sobat, which could prevent the existing flow of water, except as agreed with the British Government and the Government of Sudan. Some legal scholars tend to believe that this agreement is not binding on Ethiopia because it has not been ratified.

The London Agreement between England, France and Italy of December 13, 1906 effectively divided Ethiopia into spheres of influence and was signed without its participation. The sphere of English interests covered north-western and western Ethiopia, including the Nile Basin Rivers. Article 4a

3 Abdo M. The Nile Question: The Accords on the Water of the Nile and Their Implications on Cooperative Schemes in the Basin // Center for Strategic Research. Republic of Turkey Ministry of Foreign Affairs. URL: http://www.sam.gov.tr/wp-content/uploads/2012/01/4.Mohammed-Abdo.pdf (accessed: 03.01.2020).

${ }^{4}$ Agreement between the United Kingdom, France, and Italy, Respecting Abyssinia. Signed at London, December 13, 1906 // The American Journal of International Law. 1907. No. 2. P. 226 -230. DOI: $10.2307 / 2212390$. declared that countries should work together to ensure that the waters of the tributaries of the Nile were used and that no measures should be taken which might reduce the amount of water flowing in the direction of the main channel. In May 1929, the governments of Egypt and the United Kingdom (which owned Uganda and Kenya) reached an agreement whereby the British recognized Egypt's "natural and historical rights" to the Niles. It also provided for mandatory prior consent of the Egyptian side in resolving any question relating to the water use regime. The agreement includes, inter alia, the following provisions:

- Egypt and Sudan use 48 and $4 \mathrm{~km}^{3} /$ year of Nile runoff respectively;

- The Nile runoff during the dry season (20 January - 15 July) is retained for Egypt;

- Egypt reserves the right to control the Nile runoff in upstream countries;

- Egypt reserves the right to implement Nile-related projects without the approval of upstream coastal states;

- Egypt reserves the right to veto any construction project that adversely affects its interests [Lumumba 2007: 10-24].

It makes it abundantly clear that "without the consent of the Egyptian Government, no irrigation or hydroelectric installations may be established on the tributaries of the Nile or their lakes, if such installations are capable of causing a lowering of the water level to Egypt's detriment" 6 .

The agreement gave Egypt the right to exercise full control over the Nile during the dry season, when water is most needed for irrigation. It also strictly limited the amount of river water for the Sudan and did not provide for a share of the flow of any other coastal State. Based on an exchange of notes dated 30-31 May 1949 and 16 July 1952 between Egypt and the United

5 Exchange of Notes between Her Majesty's Government in the United Kingdom and the Egyptian Government on the Use of Waters of the Nile for Irrigation. Signed at Cairo, on 7 May 1929 // International Water Law Project. URL: https://www.internationalwaterlaw. org/documents/regionaldocs/Egypt_UK_Nile_Agreement1929.html (accessed: 02.01.2020).

${ }^{6}$ Ibid. 
Kingdom, an agreement was reached to build the Auvers Fall Dam in Uganda ${ }^{7}$. It provided that subsequent use of the dam, power plant and irrigation facilities should be carried out without prejudice to Egyptian interests. Thus, the upstream countries, despite their needs, were not able to use the waters of the Nile.

In the early 1950s, Egypt planned to build the Aswan Dam to accumulate the full flow of the Nile. Before the project was implemented, it was deemed advisable to obtain a guarantee from Sudan and international recognition to finance the dam. One of the financial donors, the International Bank for Reconstruction and Development (IBRD), made it a condition to provide a share of Sudan's water and compensation to the people who would be evicted from the dam area. In 1956, Sudan became independent and wanted to change the provisions of previously signed agreements, which it considered unfair to itself. At the beginning of negotiations, both sides demanded large quantities of water for their development. Thus, Sudan claimed $44 \mathrm{~km}^{3}$ of Nile water for irrigation of $2.22 \mathrm{mln}$ hectares. Debates on water claims delayed the signing of the agreement [Mwangi, Mbaku 2015], but regardless of whether Sudan agreed or not, the construction of the Aswan Dam was considered by Egypt as a priority for national development. In one way or another, the Sudan had to accept Egypt's terms.

On 8 November 1959, Sudan and Egypt signed an Agreement on the Full Use of Nile Waters $^{8}$. This was done without regard to the interests of other riparian countries. The basis for the 1959 Agreement was the 1929 Agreement

7 Exchange of Notes Constituting an Agreement between the Government of the United Kingdom of Great Britain and Northern Ireland and the Government of Egypt Regarding the Construction of the Owen Falls Dam in Uganda. Done in Cairo, 16 July 1952 and 5 January 1953; in force 5 January 1953 // International Water Law Project. URL: https:/www.internationalwaterlaw.org/documents/ regionaldocs/owen-falls-dam $3 . h t m l$

(accessed: 02.01.2020).

${ }^{8}$ Agreement between the Republic of the Sudan and the United Arab Republic for the full utilization of the Nile waters signed at Cairo, 8 November 1959 // FAO official website. URL: http://www.fao.org/3/w7414b/w7414b13. htm (accessed: 19.12.2019). between the United Kingdom and Egypt, which took into account the interests of Sudan. The 1959 Agreement included, inter alia, the following paragraphs:

- The annual average flow of the Nile, which is divided between Sudan and Egypt at 18.5 and $55.5 \mathrm{~km}^{3}$ respectively, has been determined.

- Annual losses due to evaporation and other factors have been agreed at about $10 \mathrm{~km}^{3}$; this amount must be deducted from the Nile's discharge before the parties can determine the share for Egypt and Sudan.

- Sudan, in agreement with Egypt, can implement projects that increase the Nile's discharge and prevent evaporation losses in the Sadda swamps of the White Nile basin. The cost and benefits of such projects should be shared equally between the parties. If such a proposal is received from other riparian countries of the Nile and in excess of the distributed volumes of the Nile's water resources, Sudan and Egypt shall consider it.

- If the proposal is accepted and the Nile waters are to be shared with the other riparian state that has determined the volume of water, it shall be subtracted from the shares of Sudan and Egypt in equal parts determined for the Aswan Dam.

- Egypt has been granted the right to build the Aswan Dam, which can fully preserve the annual flow of the Nile?

The signing of the Agreement served as a turning point in the regulation of the international legal regime of the Nile, legally confirming the exceptional opportunities for the development of the economies of both countries. Upstream countries - including East African countries such as Kenya, Uganda and Tanzania - claim that the treaties are "relics" of a colonial era during which their interests were not taken into account. The crux of the problem is that Egypt has virtually no water beyond that provided by the Nile, and that by 2020 , according to experts such as Mamdouh Hamza, a

\footnotetext{
${ }^{9}$ Understanding the Nile Basin Hydrology // Nile Basin Initiative. URL: http://nilebasin.org/index.php/about-us/ the-river-nile (accessed: 11.12.2019).
} 
serious water crisis will hit Egypt and Sudan. Egypt is claiming its 'historical right' over the watercourse.

For the country of $98 \mathrm{mln}$ inhabitants, this is a matter of national security to the extent that, in the context of the Cold War, President Sadat did not hesitate to declare, in 1979, that only the question of water could lead the country to enter into war [Larbi 2010: 191-196]. Upstream countries criticize unrestrained irrigation downstream and say that Egypt and Sudan use Nile water for commercial purposes by exporting both the resource and cash crops. Thus, these treaty disagreements make donors and banks reluctant to finance irrigation projects or dams that are illegal under international law. But Egyptian experts also point out that upstream countries have other water resources besides the Nile. For example, the Congo River (DRC) discharges 1,000 billion $\mathrm{m}^{3}$ of water annually into the Atlantic; Ethiopia has no less than 20 catchment basins; and while the Nile basin receives 1,600 billion $\mathrm{m}^{2}$ of rainwater annually, only $5 \%$ of this manna is used [Abi Chacra 2005: 489-492].

\section{Sudan - Egypt - Ethiopia Water Dispute}

On the geopolitical level, irrigation and dam construction can generate major tensions between countries sharing the same river and therefore the same resources. The Nile's waters come mainly from the highlands of Central Africa via the White Nile and from the highlands of Ethiopia via the Blue Nile [Abtew, Dessu 2019].

Of the 11 countries in the Nile basin, Egypt is the most vulnerable, as $95 \%$ of the Nile's water comes from neighbouring countries and $150 \mathrm{mln}$ people use it. The world's longest river $(6,671 \mathrm{~km})$ originates (the White Nile) in Lake Victoria (shared by Uganda, Tanzania and Kenya), but receives most of its water supply between $84 \%$ and $90 \%$ - from the Blue Nile, which flows down from the Ethiopian highlands where heavy rainfall occurs [Bouquet 2011] and where the population has grown dramatically in the last two decades.

The geographical pattern of the Nile's course has contributed greatly to Egypt's existence and the agricultural prosperity of its lower reaches. The huge bodies of water that cross the desert before reaching the Mediterranean are at the heart of Egyptian life, and if this supply were to be reduced, the human consequences would be disastrous. The United Kingdom understood this when it was colonizing Egypt and signed the Rome Protocol with Italy as early as 1891, establishing the borders between Ethiopia and Sudan but also prohibiting any attempt to alter the flow of the Atbara River (the last tributary of the Nile). In 1902, the United Kingdom took further precautions by signing a treaty with Emperor Menelik II in which the latter undertook never to undertake any development on the Blue Nile without his authorization.

The sharing of the Nile between Sudan and other riparian countries (in total 11 countries: Burundi, Democratic Republic of Congo, Egypt, Eritrea, Ethiopia, Kenya, Rwanda, South Sudan, Republic of Sudan, Tanzania, and Uganda) has been a periodic cause of tension. As soon as the country gained independence in 1956, the Sudanese demanded a renegotiation of the agreement signed in 1929 with Egypt, then a British colony. Negotiated at the time of the Anglo-Egyptian condominium and largely favourable to Cairo, the agreement provided for sharing the annual flow of the Nile, estimated at 84 billion $\mathrm{m}^{3}\left(\mathrm{~km}^{3} /\right.$ year), up to $48 \mathrm{~km}^{3} /$ year for Egypt, $4 \mathrm{~km}^{3} /$ year for Sudan, the remaining $32 \mathrm{~km}^{3} /$ year going to the Mediterranean Sea. Three decades later, the Sudanese discharge and the need for Egypt to complete the Aswan High Dam project paved the way for a new bilateral treaty in 1959, by which Egypt's share rose to $55.6 \mathrm{~km}^{3} /$ year and Sudan's to $18.5 \mathrm{~km}^{3} /$ year [Mwangi, Mbaku 2015].

According to this treaty, Egypt has a veto right on all works that could modify the flow of the Nile. But for the upstream states, these agreements are considered unfair. Despite the dissatisfaction of many states with the 1959 Agreement, which protects the monopoly of Egypt and partially Sudan over the Nile waters, the countries continued to cooperate on various current and strategic issues arising in the basin. In the early $1980 \mathrm{~s}$, a series of 
hydrometeorological studies were carried out in Egypt, Sudan, Kenya, Tanzania and Uganda with support from the United Nations Development Programme (UNDP).

In December 1992, following a series of consultations, representatives of water ministries met in Kampala to approve the establishment of the Nile Basin Technical Cooperation Committee for Development and Environmental Protection (TECCONILE). The Committee's activities are aimed at the development of the basin states in an integrated and sustainable manner through comprehensive cooperation and equitable distribution of Nile waters. The main objectives are to develop infrastructure, technology and capacity building for water resources management, as well as to develop national plans and integrate them into the Nile Basin Action Plan. TECCONILE was launched on 1 January 1993, following the signing of the agreement by ministers from Egypt, Sudan, Rwanda, Tanzania, Uganda and Zaire (Democratic Republic of Congo since 1997 ${ }^{10}$. Ethiopia and Kenya refused to join as full members because they felt that the committee could not resolve the fundamental problem of equitable water distribution.

The Cairo cooperation framework signed on July $1993^{11}$ concluded between Egypt and Ethiopia steps up the both countries will not implement water projects causing prejudice to the interests of the other. Any project aiming at reducing waste and increasing the flow of water should be discussed by both parties. Another attempt to establish a collective body to take over the revision and improvement of the existing Nile Basin Agreements was made in 1997, when the Nile State, with the assistance of UNDP, organized a forum for interstate dialogue on the legal and institutional aspects of the forthcoming Nile negotiations. A document was later

10 Agreement on the Nile River Basin Cooperative Framework. May 14, 2010 // Nile Basin Initiative. URL: https://www.nilebasin.org/nbi/cooperative-frameworkagreement (accessed: 19.12.2019).

${ }^{11}$ Framework for general co-operation between the Arab Republic of Egypt and Ethiopia signed at Cairo, 1 July 1993 // FAO official website. URL: http://www.fao.org/3/w7414b/ w7414b0p.htm (accessed: 30.11.2019). prepared, but no consensus could be reached then.

The Nile Basin Initiative (NBI) was founded on 22 February 1999 in Dar es Salaam at a ministerial meeting of the ten countries concerned. Eritrea joined the Nile Basin Initiative as an observer. This initiative was supported by the World Bank and other partners and is a regional intergovernmental organization that, through partnerships between states, aims at their sustainable socio-economic development, including through equitable use of shared Nile Basin water resources. NBI was originally conceived as a transitional institution, pending the conclusion of a joint framework agreement on cooperation and the establishment of a permanent Nile Commission. The NBI "seeks to develop the river in a cooperative manner, share substantial socioeconomic benefits, and promote regional peace and security" 12 .

On 14 May 2010, Ethiopia signed with Rwanda, Tanzania, Uganda and Kenya the "Nile basin initiative framework agreement" which creates a "Nile Basin Commission" in which decisions will be taken by majority (Article 34 a and $b^{13}$ ) and not unanimously as is the case in the NBI. This signature calling into question the "acquired rights" of Egypt and Sudan allows them to develop projects on the Nile, without having to seek the agreement of Cairo. Egypt expressed its disagreement and slammed the door of the Nile Basin Initiative which gathers the ten riparian States of the river since February 1999. De facto, Egypt's domination of the river was over [Larbi 2010: 191—196].

Having become a regional powerhouse thanks to textiles, real estate and agriculture, Ethiopia today has a growing need of $+30 \%$ per year in electricity. To ensure this need, Ethiopia has been multiplying since the 1990s programmes of hydroelectric production and

12 Nile Basin Initiative. An Overview // Nile Basin Initiative. URL: https://www.nilebasin.org/documentspublications/73-nile-basin-initiative-an-overview/file (accessed: 30.11.2019).

13 Agreement on the Nile River Basin Cooperative Framework. May 14, 2010 // Nile Basin Initiative. URL: https://www.nilebasin.org/nbi/cooperative-frameworkagreement (accessed: 19.12.2019). 
development of irrigated crops marked by the construction of dams, including the Grand Renaissance Ethiopian Dam (GERD) [Abtew, Dessu 2019], which is destined to be the largest dam in Africa. Its construction started in 2011 and was almost entirely financed by Ethiopia itself. The Renaissance dam project will reduce the Nile's flow in Egypt, which is $98 \%$ dependent on the Nile, by about $25 \%$. Aside from the environmental aspect of the construction, it has a huge signification for Ethiopia. It highlights "Ethiopia's can-do spirit"14 and imbues the country and its inhabitants with confidence when it comes to project of national and international interests. Furthermore, the keyrole played by Ethiopian engineers has stressed out the capabilities of the country in terms of construction industry and engineering [Heggy 2020].

It is worth noting that the construction of this dam is an extremely expensive project for Ethiopia. Its total cost is estimated at 4.8 billion USD (which is about $7 \%$ of Ethiopia's GDP in $2017^{15}$ ). Of this amount, external investors Chinese banks - account for 2 billion USD [Yagya, Nesterova 2018]. It agreed in 2015, with the two other Blue Nile countries, to a study on the consequences of the dam. But the Tripartite National Committee of the Renaissance Dam (which brings together Cairo, Khartoum and Addis Ababa) was unable to agree on the conclusions of a report submitted in May 2015 by two French consulting firms, Artelia and BRL, on the social and environmental impacts of the dam on Sudan and Egypt.

To understand the potential impact of this dam on Egypt [Cascao, Nicol 2016], one has to go to the Nile Delta region, the lung of Egypt's agriculture, where $30 \mathrm{mln}$ people live off the river's waters. Farmers in this region have been

${ }^{14}$ Amdetsion F. Time to Think about Ethiopia's PostGERD Nile Policy // Cooperative Waters Magazine. URL: https://www.africanidea.org/Nile_Coop_Waters.pdf (accessed: 18.12.2019).

15 Meles Launches Millennium Dam Construction on Nile River // NewsBusinessEthiopia.com. 2 April 2011. URL https:/yonastamiru.wordpress.com/2011/05/03/ millennium-dam-construction-on-nile-river/ (accessed: 09.12.2019). specialists in rice cultivation for thousands of years. However, rice farming will no longer be suitable as the river's waters recede, prompting the government to encourage the population to grow other crops [Le Floch 2010]. Very worried, Egypt talks about food security and therefore national security. Sudan is facing the same problem: a young population that is growing due to a demographic transition; a country facing development difficulties. The Blue Nile mainly supplies Sudan with $77 \%$ of its water [Yagya, Nesterova 2018], and the renaissance dam will impact the country's agriculture and energy needs. But today, Sudan seems to support the Ethiopian project.

In this matter, Egypt is quite isolated. Even Sudan, historically close to Egypt, has approached Ethiopia thinking it could benefit from irrigation facilities and electricity thanks to the Ethiopian dam. This debate on the waters of the Nile shows that the geopolitics of the region has evolved. The almighty Egypt, which in the 1970s built the Aswan dam without negotiations, is now largely in competition, economically and demographically.

According to Dr. Essam Heggy, dams with large reservoirs tend to stop the natural cycle of flooding that "distributes organically rich silt on riverbanks, enriching the arable land available, and contributing to the rhythms of the native ecosystem". He also adds that the sediment used to build up the Delta led to erosion due to an acceleration of sea water from the Mediterranean Sea into the Delta. Once-fertiles farmland is now destroyed. Nowadays scientists state that with the GERD construction, "a further disruption to the Nile's ecosystem could cause irreversible damage to the region" [Heggy 2020].

\section{Possible Ways of Solving the Problem: Bilateral Level}

Egypt, for its tries to take the lead (while keeping control of the situation) by launching various cooperation initiatives [Obengo 2016]. It has launched a policy of technical cooperation with downstream countries, known as the Endugu policy (Swahili for "cartel"). It is also cooperating with the Sudan on the Merowe dam 
project, 350 kilometres north of Khartoum. The Bujagali dam project in Uganda, at the outlet of Lake Victoria, is also supported by the NBI and therefore by Egypt (it is, on the other hand, very strongly criticized by environmentalists) [Larbi 2010: 191-196]. According to some observers, this is where the key to the problem lies: Egypt could reach an agreement that does not call into question its share of the Nile as a counterpart to an increase in its technical and financial aid to upstream countries.

The Egyptian President Abdel Fattah alSissi, his Sudanese counterpart Omar el-Bechir and the Ethiopian Prime Minister Haile Mariam Dessalegn have defused the conflict in Khartoum, the Sudanese capital, where the White Nile and the Blue Nile meet to form the Nile, before it flows into the Mediterranean [Lawson 2017]. On 23 March 2015, they signed an agreement in principle on the construction of the Ethiopian "Great Renaissance" dam and on the distribution of the waters of the great river ${ }^{16}$.

Cairo called for "the involvement of international mediation in the negotiations on the Renaissance Dam" in a communiqué issued in October 2019 by the Ministry of Irrigation, following new talks in Khartoum. "Negotiations on the Renaissance Dam are at an impasse", the Egyptian ministry added, as the Ethiopian delegation "rejected all proposals that consider Egypt's water interests"17. In another statement, the Egyptian presidency called on the United States to play "an active role" in resolving the dispute, affirming the need for third-country intervention to "break the impasse".

Technical discussions have recently been complicated by the fact that, with climate change, predictions of the impact of drought

16 La tentation du Nil: les clefs de la tension entre l'Ethiopie et l'Egypte // FranceTv info online. 20 May 2018. URL: https://www.francetvinfo.fr/monde/afrique/ soudan/la-tentation-du-nil-les-clefs-de-la-tension-entrelethiopie-et-legypte_3055285.html (accessed: 04.01.2020).

17 Barrage de la Renaissance: nouvelles tensions entre l'Egypte et l'Ethiopie sur le partage des eaux du Nil // Jeune Afrique online. 6 octobre 2019. URL: https://www.jeuneafrique.com/839354/politique/barragede-la-renaissance-nouvelles-tensions-entre-legypte-etlethiopie-sur-le-partage-des-eaux-du-nil/ 04.01.2020). events are becoming more complex, and even more vital [Swain 2011]. The last session of negotiations, which concluded in Addis Ababa on 9 January 2020, did not allow the Egyptian and Ethiopian delegations to agree on the speed at which the dam should be commissioned to preserve enough flow in the Blue Nile. Ethiopia would have liked the filling to be carried out over a period of between four and seven years, the second half of which is considered the most water intensive. For their part, the members of the Egyptian technical committee consider that this period should be extended from 12 to 21 years (and only in rainy season) to preserve the interests of their country. As the Ethiopian water minister announced after the Addis Ababa meeting: "This is not acceptable at all, at any price".

According to a report by the Geological Society of America, it would theoretically take between 5 and 15 years on average to fill the dam, but this estimate could, under certain climatic conditions, lead to a fall of a quarter of the volume of water reaching Egypt, "with a $25 \%$ drop in the production of electricity from the Aswan dam" [Prunier 2009: 173-237].

In his report for Al-Jazeera Media Group, Dr. Essam Heggy published along with other scientists the following prospects concerning the fulfilling of the dam:

- If Ethiopia fills the GERD in 21 years (which would be the best case for Egypt), "Egypt's water deficit is expected to increase by 3 billion cubic metres annually, or approximately $5 \%$ of the country's annual share of the river". Egypt would lose then less than $2.5 \%$ of its agricultural area.

- If Ethiopia fills the dam in 10 years, "Egypt's water deficit is expected to increase by 8 billion cubic metres annually, or approximately $14 \%$ of the country's annual share of the river". Egypt would lose around $18 \%$ of its agricultural lands.

- If the GERD is filled in 7 years then Egypt's water deficit is expected to "increase by 12 billion cubic metres annually, or approximately $22 \%$ of the country's annual 
share of the river". Egypt would lose around $30 \%$ of its agricultural territories.

- If the dam is filled in 5 years, it will have dramatic consequences for Egypt, that "could lose up to 20 billion cubic metres annually, or approximately $36 \%$ of its water share." About half of Egypt's total agricultural area could be lost".

- If the GERD is filled in 3 years, the most dramatic scenario would occur for Egypt: "It could lose approximately $50 \%$ of its water share and about $67 \%$ of [it']s agricultural area could be lost" [Heggy 2020].

\section{Multilateral Level and International Mediation}

The support of the international community remains critical in encouraging and consolidating cooperation among the Nile basin countries. This concerns first, of course, financial support. The establishment of the NBI has undeniably made it possible to attract more international aid, as the case of the Bujagali dam shows. The World Bank had theoretically refused to invest in Sudan because of the country's political situation, but it did so through the NBI. Technical support and expertise are equally important, however, and common arrangements for all countries are also a way of strengthening their collaboration and getting them used to working together. Of particular note is a project, supported by Italy and FAO, to develop information and management systems for water resources in the Nile basin, which should enable the countries concerned to make better-informed decisions in this area.

Another example is the Nile Basin Research Programme of the University of Bergen (Norway), which aims, among other things, to train high-level personnel in the 10 countries concerned to manage the waters and ecosystems of the Nile basin ${ }^{18}$.

18 Bouguerra L., Petitjean O. Le partage des eaux du Nil : conflits et coopérations // Partage des eaux online. 07.09.2009. URL: https://www.partagedeseaux.info/ Le-partage-des-eaux-du-Nil-conflits-et-cooperations (accessed: 30.11.2019).
However, Ethiopia, Sudan and Egypt are not the only countries affected by the conflict. 6 of 11 countries bordering the Nile had signed the Entebbe agreement in $2010^{19}$ paving the way for a more equitable and wider sharing of the waters. Some of these countries have tributaries of the Nile on their territory. The total population of the riparian countries, counting broadly, is $40 \%$ of that of the continent. The agreement, unlikely to calm the spirits in Egypt, paved the way for more sophisticated negotiating formulas than the allor-nothing approach that has prevailed so far.

In 2015, in a phase of détente, a "declaration of principle" 20 was then signed in Khartoum by Egypt, Sudan and Ethiopia. Technical committees from each country were then set up to lay the foundations for a water-sharing agreement - and thus for the operation of the Renaissance dam — with the support of international experts.

In Ethiopia, the arrival in power in April 2018 of the new Prime Minister Abiy Ahmed had even hinted at the possibility of speeding up the resolution of this issue. In May, negotiations to this end began. During an emotionally charged visit, Abiy Ahmed then travelled to Cairo, where he gave a speech of almost delirious optimism, promising that Egypt would be given "more water" than it had received so far.

The lack of concrete results had again led to tensions, which were only calmed down at the Sochi Africa - Russia Summit in October 2019. Then, the following month, a US initiative was launched in Addis Ababa, led by Treasury Secretary Steven Mnuchin, with the assistance of the World Bank. Egypt, Sudan and Ethiopia organized the area of disagreements "in one document, signed minutes and communicated jointly", tweeted Seleshi Bekele Awulachew, Minister of Water, Irrigation and Energy of the Federal Democratic Republic of Ethiopia ${ }^{21}$. It

19 Who controls the world's longest river? // Reuters. April 23, 2018. URL: https://www.reuters.com/article/ us-egypt-rice-factbox/who-controls-the-worlds-longestriver-idUSKBN1HU1OE (accessed: 15.12.2019).

${ }^{20}$ Ibid.

21 Tekuya M. Sink or Swim: Unlocking the Nile Impasse // Ethiopia Insight. December 8, 2019. URL: 
was expecting the three countries concerned to reach an agreement on 15 January 2020. The agreement was intended to regulate the conditions for filling the dam (and not to discuss its merits), establishing a water-sharing policy. If no agreement was reached by 15 January 2020 , an international mediator would have to be appointed.

It is in this context that the Ethiopian Prime Minister visited South Africa on 11-12 January 2020. Abiy Ahmed offered the South African President, Cyril Ramaphosa, to play this role, saying that he had the advantage of being "a friend of both Ethiopia and Egypt", and that, taking over the rotating presidency of the African Union in early February 2020, he was fully qualified to engage in negotiations "in order to resolve the problem peacefully" 22 . In the complex part that is being played out over the waters of the Nile, where the main interested parties, riparian countries of varying weight, but also influential Gulf countries in the Horn region and North Africa, are involved, the choice of South Africa as mediator, if confirmed, would not be obvious: the country does not have the necessary expertise and suffers from a continental influence that has been strongly eroded since the period of former president Jacob Zuma. Two assets those are nevertheless indispensable for overcoming the contradictory aspirations of Ethiopia and Egypt.

\section{Concluding Remarks}

The scarcity of water resources, aggravated by population growth, economic growth and the consequences of global climate change, has fuelled the assumption that "water wars" are imminent and will mark the 21st century. However, despite this conjecture, no armed conflict over water has yet taken place. While access to water has been a catalyst for some

https://www.ethiopia-insight.com/2019/12/08/sink-orswim-unlocking-the-nile-impasse/ (accessed: 02.01.2020).

${ }^{22}$ L'Afrique du Sud peut-elle résoudre le conflit sur les eaux du Nil? // Nouvelles du monde. January 14, 2020. https://www.nouvelles-du-monde.com/lafrique-du-sudpeut-elle-resoudre-le-conflit-sur-les-eaux-du-nil/ (accessed: 16.01.2020). inter-state tensions, it has never been the sole or main reason for the outbreak of war. The cases of the Jordan and Nile basins illustrate the importance of cooperative mechanisms for the regulation of water resources. Contrary to a widely held belief, the presence of a hegemon among the countries bordering the river is not always conflicting, and the real determining variable is rather the existence of institutionalized cooperation mechanisms and alternative channels for meeting the needs of the different countries. However, the problem of water scarcity is likely to persist and worsen in the future and will require effective solutions not only for individual access to freshwater, but also for sharing transboundary water resources. Improving the management and distribution of scarce water resources is vital for growth and geopolitical stability in the Middle East and North Africa, according to the World Bank. In this perspective, it is essential that clear and effective rules for the international sharing of water resources be established, which would avoid conflicts and provide a sound basis for cooperative solutions.

Today, the geopolitical configuration of the forces among the key Nile riparian states remains ambiguous: if the status quo changes, Egypt will suffer, and if the status quo persists, the interests of the Upper Nile states that lack access to water sources on their own territory will continue to be infringed. How long such a situation will last, given the highly mobile geopolitical situation in the region, is a big question. In order to justify the current sharing of waters, Egypt constantly recalls its very strong dependence on the Nile, unlike the upstream States, which can take advantage of abundant equatorial rains, among other things. It believes that if those States have been able to live without the Nile, they should be able to continue to live without it. However, this argument cannot justify the intransigence of Egypt and the Sudan. With a flow of 84 billion cubic metres, the Nile is a low-level river. Every year, $10 \%$ of the water evaporates because Lake Nasser is in the middle of a desert region [Yagya, Nesterova 2018]. The construction of dams upstream of the Nile would make it possible to combat this evaporation. But the Egyptians do 
not conceive that major developments on the Nile can be made elsewhere than on their territory. All states, including Egypt, must benefit from integrated management of the Nile basin.

Moreover, the validity and/or enforceability of the treaties which have given rise to the sharing of the waters of the Nile should be challenged. Neither agreement took into account the water needs of other riparian states that were not parties to the agreement, including Ethiopia, whose Blue Nile provides a large part of the river's waters. It is then difficult to recognize the customary character of the historical rights on which it relies. It is imperative that Egypt and Sudan make concessions. The current use obviously deserves to be considered, but this cannot be the only criterion. States involved must return to the negotiating table and cooperate in good faith as required by international law. The conclusion of a framework agreement encompassing all Nile basin states must not be akin to the search for the sources of the Nile, in other words, an impossible goal. An international mediation seems to be for now one of the best options in order to find a common path to this issue.

Received / Поступила в редакцию: 18.01.2019 Accepted / Принята к публикации: 25.02.2020

\section{References / Библиографический список}

Abi Chacra, E. (2005). Les eaux du Nil: désamorcer les conflits par le partage équitable. Outre-Terre, 11 (02), 489-492. (In French). DOI: 10.3917/oute.011.0489

Abtew, W. \& Dessu, S.B. (2019). The Grand Ethiopian Renaissance Dam on the Blue Nile. Berlin: Springer. DOI: 10.1007/978-3-319-97094-3 8

Amer, K., Adeel, Z., Böer, B. \& Saleh, W. (Eds.). (2017). The Water, Energy, and Food Security Nexus in the Arab Region. Berlin: Springer. DOI: 10.22363/2313-0660-2019-19-3-515-517

Bencala, K.E. \& Dabelko, G.D. (2008). Water Wars: Obscuring Opportunities. Journal of International Affairs, 61 (02), $21-34$.

Bouquet, C. (2011). Conflits et risques de conflits liés à l'eau en Afrique. Les Cahiers d'Outre-Mer, 255, 341-362. (In French). DOI: 10.4000/com.6283

Cascao, A.E. \& Nicol, A. (2016). GERD: New Norms of Cooperation in the Nile Basin? Water International, 41 (04), 550—573. DOI: 10.1080/02508060.2016.1180763

Heggy, E. (2020). Could Mega-Dams Kill the Mighty River Nile. Al-Jazeera Report. URL: https://interactive.aljazeera.com/aje/2020/saving-the-nile/index.html (accessed: 14.02.2020).

Larbi, B.M. (2010). L'Egypte, l'Initiative du Bassin du Nil, et les «autres». Confluences Méditerranée, 75, 191196. (In French). DOI: 10.3917/come.075.0191

Lawson, F. (2017). Egypt versus Ethiopia: The Conflict over the Nile Metastasizes. The International Spectator, 52 (04), 129-144. DOI: 10.1080/03932729.2017.1333272

Le Floch, G. (2010). Le difficile partage des eaux du Nil. Annuaire français de droit international, 56, 471-496. (In French). DOI: 10.3406/afdi.2010.4622

Lumumba, P.L.O. (2007). The Interpretation of the 1929 Treaty and Its Legal Relevance and Implications for the Stability of the Region. African Sociological Review, 11 (01), 10-24. DOI: 10.4314/asr.v11i1.51419

Markakis, J. (1998). Resource Conflict in the Horn of Africa. Uppsala: Uppsala University.

Mason, S.A. (2004). From Conflict to Cooperation in the Nile Basin. Interaction between Water Availability, Water Management in Egypt and Sudan, and International Relations in the Eastern Nile Basin. Forschungsstelle für Sicherheitspolitik, ETH Zürich.

Mwangi, K.S. \& Mbaku, J.M. (2015). Governing the Nile River Basin: The Search for a New Legal Regime. Washington: Brookings Institution Press.

Obengo, J.O. (2016). Hydropolitics of the Nile: The Case of Ethiopia and Egypt. African Security Review, 25 (01), 95-103. DOI: $10.1080 / 10246029.2015 .1126527$

Prunier, G. (2009). Le bassin du Nil: des mythes à l'hydropolitique. In: Raison, J.-P. (Eds.). Des fleuves entre conflits et compromis. Essais d'hydropolitique africaine. Paris: Editions Karthala, «Hommes et sociétés». P. 173-237. DOI: 10.3917/kart.raiso.2009.01.0173 
Smirnova, G.I. \& Gukasyan, G.L. (2019). Ecological Problems of the Republic of Sudan. In: Filonik, A.O. (Eds.). Arab East: Green Growth and the Challenges of the Present. Moscow: Institut vostokovedeniya RAN publ. P. 223-262. (In Russian).

Swain, A. (2011). Challenges for Water Sharing in the Nile Basin: Changing Geo-politics and Changing Climate. Hydrological Sciences Journal, 56 (04), 687-702. DOI: 10.1080/02626667.2011.577037

Tadesse, D. (2008). The Nile: Is It a Curse or Blessing? Institut d'études de sécurité, ISS Paper 174, novembre.

Vasiliev, A.M. \& Elkina, E.A. (2018). Dividing of the Nile Water: A Way of Looking through the Prism of History. Voprosy istorii, 10, 20-28. (In Russian).

Yagya, V.S. \& Nesterova, I.E. (2018). The Nile Question Yesterday and Today. Asia and Africa Today, 5, 28-32. (In Russian). DOI: 10.7868/S0321507518050057

\begin{abstract}
About the authors: Abdullah Adam Muhammad Ahmed - Professor, Department of Political Science, Al-Zaeem Al-Azhari University, Khartoum, Sudan (e-mail: sooni2010@gmail.com).

Dyduck Celia - Assistant, Department of Theory and History of International Relations, Peoples' Friendship University of Russia (RUDN University) (e-mail: celiadyduck@yahoo.fr).

Ahmed Taha Y. - postgraduate student, Department of Theory and History of International Relations, Peoples' Friendship University of Russia (RUDN University) (e-mail: tahahassan88@gmail.com).
\end{abstract}

Сведения об авторах: Абдулла Адам Мухаммад Ахмед - профессор, департамент политических наук, Университет Аль-Заим Аль-Азхари, Хартум, Судан (e-mail: sooni2010@gmail.com).

Дидук Селия - ассистент кафедры теории и истории международных отношений, Российский университет дружбы народов (e-mail: celiadyduck@yahoo.fr).

Ахмед Таха Я. - аспирант кафедры теории и истории международных отношений, Российский университет дружбы народов (e-mail: tahahassan88@gmail.com). 